\title{
AN OVERVIEW OF ENVIRONMENTAL IMPACT ASSESSMENT IN TURKEY: ISSUES AND RECOMMENDATIONS*
}

\author{
Deniz TEKAYAK ${ }^{* *}$
}

\begin{abstract}
Since its introduction, Environmental Impact Assessment (EIA) has become an important tool for planning, environmental management, environmental decision making and environmental preservation in European Union (EU) and in Turkey as well. This article provides an overview of Turkey's EIA system by underlining the role that Turkey's candidacy to EU plays on development and strengthening of Turkish EIA process. In this context, the article presents historical evolution of EIA system in European Union to provide a background for understanding and evaluating the developments in Turkish EIA system. Following this, article lays down the legal framework of Turkish EIA system and addresses the issues that Turkish EIA system faces with regard to transposition and effective implementation of EU's EIA law. Finally, the article concludes by proposing several measures and mechanisms to overcome the weaknesses of Turkish EIA system and improve the effective implementation of the EIA legislation in Turkey.
\end{abstract}

Keywords: European Union, Turkey, Environmental Impact Assessment

\section{Türkiye'deki Çevresel Etki Değerlendirmesi’ne Genel Bir Bakış: Sorunlar ve Öneriler}

\section{Özet}

Ortaya çıktı̆̆ tarihten bu yana Çevresel Etki Değerlendirmesi (ÇED), Avrupa Birliği ve Türkiye'de planlama, çevresel yönetim, çevresel karar alma ve çevre koruma süreçlerinin önemli bir aracı haline gelmiştir. Bu makale, Türkiye'nin Avrupa Birliği adaylı̆̆ının Türkiye'deki ÇED süreçlerinin gelişmesinde ve güçlenmesinde oynadığı rolü de göz önüne alarak, Türkiye'nin ÇED sistemine genel

\footnotetext{
* This article is based on author's master's thesis titled 'Environmental Impact Assessment Law and Practice: The EU and Turkey'.

${ }^{* *} \mathrm{PhD}$ student at University of Burgundy in Faculty of Law and Political Science
} 
bir bakış sunmaktadır. Bu bağlamda, bu makalede, Türkiye’nin ÇED sistemindeki gelişmelerin daha iyi anlaşılmasına ve değerlendirilmesine temel oluşturmak için, ÇED'in Avrupa Birliği'ndeki tarihsel gelişimi ortaya konulmaktadır. Bunu takiben, Türkiye'deki ÇED süreçlerinin hukuki çerçevesi incelenmekte ve Türk ÇED sisteminin Avrupa Birliği çevre mevzuatı ile uyumlaştırılmasında ve genel uygulamada yaşanan sorunlar ele alınmaktadır. Son olarak, Türk ÇED sistemindeki eksikliklerin giderilmesi ve uygulamadaki sorunların üstesinden gelinmesine yardımcı olabilecek bir dizi öneri sunulmaktadır.

Anahtar kelimeler: Avrupa Birliği, Türkiye, Çevresel Etki Değerlendirmesi

\section{Introduction}

World has started to witness an unprecedented economic development and environmental degradation after the Second World War. Mass housing projects, new jobs, emerging industries and technological advancements caused serious environmental degradation especially in Europe and the United States. During the second half of the 1960s, public awareness about growing environmental problems began to rise. In 1972, Club of Rome, a group of people comprised of businessman, scientists and politicians, carried out a research with the researchers from Massachusetts Institute of Technology. This study showed that, with present (1972) rates of consumption of resources, the limits to growth on the earth would be reached within one hundred years. ${ }^{1}$ However, findings of the study also revealed that it was possible to change the present situation through establishing a balance between economic growth and environmental preservation.

As a result of growing interest and awareness, new pieces of legislation that aimed to balance the relationship between environment and development were started to be introduced both in the United States and in Europe. Environmental Impact Assessment (EIA) was one of the most important examples to newly emerging legislation that aimed to preserve this balance. The International Association for Impact Assessment (IAIA) defines EIA as: "the process of identifying, predicting, evaluating and mitigating the biophysical, social, and other relevant effects of development proposals prior to major decisions being taken and commitments made.",2

It was first introduced in United States in 1969 through National Environment Policy Act (NEPA) and considered to be a very significant and unprecedented measure in environmental law and policy. It introduced a

\footnotetext{
${ }^{1}$ Club of Rome, "The Limits to Growth", http://www.clubofrome.org/?p=326 (Accessed on March 2, 2013).

${ }_{2}^{2}$ International Association for Impact Assessment (IAIA), "Principles of Environmental Impact Assessment Best Practice", 1999. Retrieved from http://www.iaia.org/publicdocuments/special-publications/PrincipleofIA_web.pdf (Accessed on July 19,2012 ).
} 
national policy on the preservation and restoration of environmental quality and aimed to establish a system in which federal government agencies take environmental impacts into account during decision making process. NEPA required all federal government agencies to make an analysis and evaluation of all the environmental effects of their programmes. Framework and principles of NEPA have influenced numerous countries and international organizations to formulate their own EIA systems. NEPA has also constituted an important model for the development of EIA law and policy in the European Union (EU).

\section{Historical Evolution of the European Union's EIA Law and Practice}

In 1970s, public concern over environmental degradation was growing across the Europe. The European Commission stated that too much economic activity has taken place without using environmentally-friendly technology and that the impacts of these activities on environment should be taken into account during planning and decision making. ${ }^{3}$ Hence, the Commission started working on introduction of a uniform EIA system for all Member States. Such a system was desired for two reasons. Firstly, a uniform EIA would introduce measures to limit environmental degradation and foster environmental protection in all Member States. Secondly, this uniform system would prevent distortion of competition in cases where one Member State could gain unfair advantage by allowing projects that will harm the environment of another Member State. ${ }^{4}$ Thus, after lengthy discussions on various draft proposals, the EIA Directive (Directive 85/337/EEC) was adopted in 1985.

EIA introduced by the European Commission is a process which aims to enable high level of environmental protection as well as integration of environmental considerations into preparation of development projects. Upon its adoption, the EIA Directive provided a flexible framework for Member States. The Directive laid out a general framework and left the details to be specified by Member States. Mainly, the Directive necessitated certain group of public and private projects to be assessed to determine their significant impacts on environment before the approval of the projects.

Apart from assessment procedure and steps that should be followed during an EIA process, the Directive included provisions on public

\footnotetext{
${ }^{3}$ Christopher Wood, "Environmental Impact Assessment: A Comparative Review", 2nd Edition, Harlow: Prentice Hall,2003, p.35.

${ }^{4}$ John Glasson et al., "Introduction to Environmental Impact Assessment", 3rd Edition, New York: Routledge, 2005, p. 40.
} 
participation which is considered to be a very important pillar of the EIA process. Public participation was officially recognized and incorporated into the European Union's legislation with Directive 85/337/EEC, Directive 90/313/EEC, Directive 2001/42/EC, Directive 2003/35/EC; and United Nations Economic Commission for Europe's (UNECE) Espoo Convention, Protocol on Strategic Environmental Assessment, Aarhus Convention.

Aarhus Convention, otherwise known as the UNECE Convention on Access to Information, Public Participation in Decision-Making and Access to Justice in Environmental Matters, is an international environmental treaty which was signed on June 1998 by more than thirty five European and Central Asian countries. The United Nations Economic Commission for Europe, a United Nations (UN) organization which aims to achieve economic integration and cooperation among its members, organized the Aarhus Convention with the contributions of numerous environmental agencies and non-governmental organizations. This Convention played significant role in introducing broad and democratic principles with regard to public participation in environmental decision making and access to environmental information. Aarhus Convention constituted an important step towards democracy since it underlined the importance of transparency, availability and accessibility of information regarding decisions made on environmental matters. After the EU became a Party to the Convention, the Public Participation Directive (Directive 2003/35/EC) was introduced to ensure compliance with the Aarhus Convention.

Another important UNECE treaty which introduced important principles that strengthen the EIA framework was the Convention on Environmental Impact Assessment in a Transboundary Context (otherwise known as the Espoo Convention). The EIA Directive had a significant influence on the work of UNECE in the development of the Espoo Convention. ${ }^{5}$ The Convention cuts across environmental problems and tries to address wide variety of environmental problems so long as the effects of those problems have an impact on a state outside the source state. ${ }^{6}$ The Espoo Convention urges its signatories to consult each other on all significant projects which are likely to have important adverse transboundary impacts on other states. The Convention was signed in 1991 by the European Union along other countries and it entered into force in 1997. Initially, development of the Espoo Convention was influenced by the EIA Directive.

\footnotetext{
${ }^{5}$ Simon Marsden, "Strategic Environmental Assessment in International and European Law: A Practitioner's Guide", London; Sterling, VA: Earthscan, 2008, p.74.

${ }^{6}$ Neil Craik, "The International Law of Environmental Impact Assessment: Process, Substance and Integration”, UK: Cambridge University Press, 2010, p.102.
} 
Upon its introduction, Espoo Convention played an influential role in strengthening the procedural base of the EIA Directive. After becoming a Party to the Convention, EU has introduced Directive 97/11/EC (amendment to the EC Directive 85/337) to incorporate the provisions of the Espoo Convention into the EIA Directive.

EU has further strengthened its EIA system by introducing the Strategic Environmental Assessment Directive (Directive 2001/42/EC). During the formulation of the original EIA Directive, a discussion took place about whether to include assessment of strategic proposals into the EIA Directive. However, during the negotiations, several Member States opposed possible incorporation of strategic assessment of plans and programmes. Hence, the promulgation of strategic environmental assessment was delayed for many years until the adoption of the Strategic Environmental Assessment Directive (SEA Directive) in 2001. The SEA Directive advocates assessment of the environmental effects of certain public plans and programmes. Similar to EIA, SEA lays down a scheme of strategic assessment process which includes screening, scoping, public participation, decision making and postdecision monitoring. Since its introduction, the SEA Directive has become an important tool for integration of environmental considerations into economic decisions. In addition to this, the SEA Directive had a significant influence on the development of the Protocol on Strategic Environmental Assessment to the UNECE Espoo Convention (otherwise known as the SEA Protocol). This Protocol focused on establishing procedural SEA requirements in a national context and was signed by European Union and various UNECE Member States. $^{7}$

EU's Environmental Action Programmes (EAPs) have significantly contributed to the development and broadening of EIA across the Union. EAPs lay down general policy framework for EU's environmental policy. Starting from the adoption of the first EAP in 1973, all EAPs underlined the importance of taking environmental impacts into account at the earliest stage possible. Especially the Sixth EAP played a significant role in strengthening the EIA process. It underlined the necessity to improve the implementation of the EIA Directive to be able to integrate environmental concerns into land-use planning and management processes. Being entered into force in January 2014, the Seventh EAP addresses the shortcomings of Sixth EAP and introduces a long term vision to respond environmental challenges.

As a result of all the above mentioned developments, EU felt the need to revise its EIA process several times. Up until now, the EIA Directive went

\footnotetext{
${ }^{7}$ Simon Marsden, "Strategic Environmental Assessment in International and European Law: A Practitioner's Guide”, London; Sterling, VA: Earthscan, 2008, p.93.
} 
through three different revisions. These revisions were done to adopt the EIA Directive to the changing nature of EU, changing environmental problems and issue as well as making the Directive in line with the requirements introduced in international conventions that EU had signed. The EIA Directive was revised in 1997 for the first time due to its shortcomings in screening process, transboundary EIA, public participation and post-decision monitoring. However, despite some substantial amendments, the Directive continued to attract criticisms. In time, the need to further revise the EIA Directive became crucial. Hence, the Directive was revised for the second time in 2003 to incorporate principles about public participation and access to environmental information of Aarhus Convention into the EIA Directive. This amendment also aimed to strengthen the core principles of EIA process. In 2009, the EIA Directive was revised for the third time. The 2009 amendments broaden the scope and number of projects which were listed under Annex 1 and Annex 2. In 2011, all three revisions were codified by Directive 2011/92/EU.

Since its introduction, EIA Directive has become a significant tool for environmental management and protection across the European Union. The Directive introduced rules and obligations that were unprecedented for most of the Member States hence, this has resulted in problems with regard to correct and complete transposition and effective practical application of EIA legislation. Several of these problems are result of the unclear nature of some provisions of the EIA Directive. In some cases, differences in implementation levels and operational compliance are related with country's lack of previous experience on environmental law making and implementation. In addition to this, lack of a culture that acknowledges the importance of preservation of environment made correct transposition and implementation of EIA legislation harder. Apart from these, there is a lack of uniform EIA practice throughout the EU. This results in significant level of implementation differences among Member States and causes irregularities in different steps of EIA. Moreover, the lack of harmonized EIA practice causes significant problems when one or more Member States carry out transboundary EIA.

Having reviewed historical evolution of the EIA law and practice in the $\mathrm{EU}$, in the following section this article will focus on development of EIA law and practice in Turkey by taking EU's influence into account since the EIA Directive played a significant role in the development of Turkish EIA system and introduction of the EIA By-law. EU's influence on Turkish environmental law and EIA law undoubtedly increased when Turkey became a candidate country for EU membership in 1999 after the Helsinki European Council (Helsinki Summit). In March 2001, Turkish government announced 
the National Programme for adoption of the acquis communautaire ${ }^{8}$. In 2002 Copenhagen European Council, EU agreed to start accession negotiations in October 2005. On October 2005, European Council adopted Negotiating Framework that laid out the principles that characterized negotiations and a screening process was launched to examine the acquis communautaire.

As one of the conditions for full accession, Turkey has to adopt the entire body of EU law. In other words, to become a full member, Turkey has to close thirty-five chapters of acquis communautaire successfully. Environment chapter, which was opened for negotiations on December 2009, is among the EU legislation that Turkey has to fully transpose and implement. Environmental impact assessment, being an integral part of environmental law, is among the subjects that Turkey needs to achieve full compliance with EU's EIA law.

\section{Historical Evolution of EIA in Turkey}

In Turkey, as in Europe, concern over environmental degradation and necessity to take certain measures to preserve the environment increased in late 1970s and early 1980s. Turkey introduced its first environmental legislation, Environment Code No. $2872^{9}$ in 1983.

The objective of the Environment Code is defined as "to protect and improve the environment which is the common asset of all citizens; make better use of, and preserve land and air pollution; by preserving the country's vegetative and livestock assets and natural and historical richness, organize all arrangements and precautions for improving and securing health, civilization and life conditions of present and future generations in conformity with economical and social development objectives, and based on certain legal and technical principles" in Article $1 .{ }^{10}$

Apart from underlining the importance of preserving and protecting environment, Environment Code has also made a reference to EIA. EIA has gained a legal stand with Article 10 of the Environment Code which reads "the institutions, agencies and establishments that can lead to environmental

\footnotetext{
${ }^{8}$ Acquis communautaire is the collection of common rights and obligations which bind all the Member States together within the European Union. It includes Treaties, laws, case law of the Court of Justice of the European Union, declarations, resolutions, international agreements concluded by the Union and those concluded by the Member States between themselves with regard to the Union's activities. Retrieved from http://europa.eu/legislation_summaries/glossary/community_acquis_en.htm (Accessed on April 20, 2013).

9 In some sources "Environment Law No. 2872" is used instead of "Environment Code No.2872”.

${ }^{10}$ Official Gazette dated August 11, 1983, numbered 18132, Article 1.
} 
issues due to their planned activities will prepare an Environmental Impact Assessment Report. In this report all impacts on the environment will be considered and the methods for eliminating the harmful impacts of wastes and scraps that may cause environmental pollution and corresponding precautions will be specified. The issues concerning the type of projects that this Environmental Impact Assessment Report will be required, its contents and the endorsement authority will be specified in a regulation." 11

In 2006, Code No. 5491 amended the Environment Code. Revised version incorporated sustainable development among its objectives. It also reasserted the significance of protecting biological diversity and introduced penal sanctions against damage to the environment, including the destruction of biological diversity, when detected through inspection and audits. ${ }^{12}$

As explained above, EIA was already mentioned in Environment Code No. 2872. However, it required establishment of a more comprehensive legal framework. Hence, on 7 February $1993^{13}$, By-law on Environmental Impact Assessment was promulgated on the basis of Article 10 of the Environment Code No. 2872. The purpose of the EIA By-law is "to regulate administrative and technical principles and procedures for the process of Environmental Impact Assessment". ${ }^{14}$ Until now, the EIA By-law dated 7 February 1993 underwent six major revisions due to problems in implementation and Turkey's obligation to harmonize its national law with the EU's law. ${ }^{15}$ Latest revision dated 25 November $2014^{16}$ attracted criticism from EIA practitioners, environmental engineers, environmental activists and many more. ${ }^{17}$ Latest revision amended the projects listed under Annex 1 and Annex 2 and opened up the way for certain projects to get exempted from the requirement to automatically prepare an EIA report.

At present, Turkey has achieved certain degree of compliance with regard to EIA legislation since majority of the EIA Directive has been transposed into national legislation via EIA by-law. Except for articles

${ }^{11}$ Ibid., Article 10.

12 Official Gazette dated May 13, 2006, numbered 26167.

${ }^{13}$ Official Gazette dated February 7, 1993, numbered 21489.

${ }^{14}$ Official Gazette dated July 17, 2008, numbered 26939.

${ }^{15}$ First five revisions were done on the following dates: 23 June 1997 (Official Gazette No:23028), 6 June 2002 (Official Gazette No:24777), 16 December 2003 (Official Gazette No:25318), 17 July 2008 (Official Gazette No:26939), 3 October 2013 (Official Gazette No:28784).

${ }^{16}$ Official Gazette dated November 25, 2014, numbered 29186.

17 Aysel Alp, "AVM, golf, toplu konut projeleri ÇED'den muaf tutuldu", Hürriyet, 26 November 2014, http://www.hurriyet.com.tr/ekonomi/27647444.asp (Accessed on December $20,2014)$. 
related with transboundary EIA, in its wording, current EIA By-law is fully harmonized with the EU's EIA Directive. Another exception is that, despite being a member of UNECE since 1947, Turkey has neither signed nor ratified the Convention on Environmental Impact Assessment in a Transboundary Context, or Convention on Access to Information, Public Participation in Decision-Making and Access to Justice in Environmental Matters.

\section{Legal Framework of EIA Process in Turkey}

In Turkey, the EIA Regulation was drafted by the former Ministry of Environment in 1993. Before the establishment of Ministry of Environment in 1991, General Directorate of Environment was the responsible body in terms of environmental matters since its establishment in 1978. In 2003, Ministry of Environment merged with Ministry of Forestry, thus formed the Ministry of Environment and Forestry. In June 2011, Ministry of Environment and Forestry became Ministry of Environment and Urbanization. Currently, "General Directorate of Environmental Impact Assessment, Permits and Control" which is designated under Ministry of Environment and Urbanization, is responsible for monitoring and inspection of projects which are within the scope of EIA.

Main structure of the EIA system in Turkey is very similar to the structure of the European Union's EIA Directive. Similar to EIA in European Union, EIA process in Turkey can be defined as: "studies to be carried for determining the likely positive or negative impact that the projects will have on environment; studying possible environmental protection measures relating to these projects in order to minimize negative effects; determining and assessing selected technological alternatives and locations; monitoring and controlling the implementation of such projects." 18

According to the EIA By-law, preparation of an EIA report is obligatory for projects listed under Annex 1, projects listed in Annex 2 with "Environmental Impact Assessment is Required" decision has been made and projects whose total capacity increase is equal to or above the threshold value given in Annex 1. For projects which are listed under Annex 2, the developer must submit a petition to the Ministry of Environment and Urbanization asking for an examination to determine if an EIA application is required for the project that he is planning to implement. Upon the submission of the request, the Ministry makes a decision of "Environmental Impact Assessment is Required" or "No Environmental Decision is

${ }^{18}$ Official Gazette dated July 17, 2008, numbered 26939, Article 3. 
Required". After receiving the decision, developer has to start the project in five years since before the validity of the decision expires within five years. The projects that received "Impact Assessment is Required" decision undergo EIA procedure like the rest of the projects which are subject to EIA process.

Before the realization of any project which is under the scope of mandatory EIA, the developer of the project must apply to General Directorate of EIA, Permits and Inspection with EIA Application File, which is prepared in line with the requirements stated in the EIA By-law. Upon the presentation of the file, General Directorate of EIA, Permits and Inspection examines the documents and information to determine if the file was prepared correctly. In cases of incorrect preparations, deficiencies and nonconformities, developer reviews and corrects the file and resubmits it to the General Directorate. Once the format of the file is approved, a Commission ${ }^{19}$ consists of project owner, representatives of related organizations, institutions and officials from Ministry of Environment and Urbanization is formed. Also, a copy of the application file is sent to related governorate. After governorate receives the file, it makes an announcement to public about the initiation of an EIA process regarding a particular project and invite public to submit their opinions and questions. Hence, a public participation meeting is arranged at the location of the project by the project owner or governorate. Upon the determination of the meeting place, the project owner is responsible for announcing the meeting in national and local newspapers at least ten days before the date of the actual meeting.

After the completion of public meetings and hearing, the Commission gathers to get more information on environmental impacts of the projects as well as the outcome of the public meeting. If some of the representatives of the Commission have attended the public participation meetings, their recommendations and opinions regarding the outcome of the public participation meetings are taken into consideration during the commission gathering. After evaluating these pieces of information, Commission determines the scope of the assessment, format of the Environmental Impact Assessment Report and the working group that will prepare the Report. After receiving these pieces of information, developer is under the obligation to submit the EIA report to Ministry of Environment and Urbanization within

19 EIA By-law defines the Commission as "the Scoping, Examining and Evaluation Commission established by the Ministry in order to determine the scope and criteria of the special format given to a project and to examine and assess the EIA Report which is prepared in line with these principles". Official Gazette dated July 17, 2008, numbered 26939, Article $4(\mathrm{r})$. 
one year. Generally, EIA Reports are prepared by eligible firms which have an EIA Proficiency Certificate given by the Ministry that allows them to prepare EIA reports and EIA application files.

When the Ministry receives the EIA report, it evaluates the report to determine if it has been prepared in correct format and by professionals who should have been part of the formation of the working group. Once Ministry decides the report is compliant with the requirements, a meeting with Commission members is arranged to assess the EIA Report in detail. Commence of the examination and assessment process and submission of the EIA Report is announced to the public on internet and also by other means. The EIA Report is made available to public at the center of Ministry of Environment and Urbanization, on its official website and at Provincial Directorates.

While assessing the EIA Report, Commission examines the accuracy and adequacy of information and documents presented and whether an effective public participation meeting has been conducted. If deems necessary, Commission may conduct studies, request detailed information, tools, measurements from the developer during the assessment. After the finalization of the assessment of the EIA Report, developer submits the Report to the Ministry. By taking the public opinion and the studies of the Commission into account, Ministry gives an "Environmental Impact Assessment is Positive (EIA Positive)" or "Environmental Impact Assessment is Negative (EIA Negative)" decision. This final decision is announced to the public with its reasons.

The decision of "EIA Positive" indicates that as a result of the measures to be taken, negative environmental impacts of a proposed project can be kept at acceptable levels and thus the project is applicable whereas the decision of "EIA Negative" means that the realization of a proposed project is not advised due to significant negative impacts. ${ }^{20}$ After receiving EIA Positive decision, the developer has to initiate the project within seven years, before the expiration of the validity of the decision. The developer that received EIA Negative decision may make a new application in cases which there is a change in all the conditions that resulted in EIA Negative outcome.

Last step in Turkish EIA process is post-decision monitoring during construction and operational phases. The Ministry of Environment and Urbanization monitors and controls projects which "EIA Positive" or "EIA is Not Required" decision has been made. In addition to this, the developer is

${ }^{20}$ Official Gazette dated July 17, 2008, numbered 26939, Article 4(h), Article 4(1). 
under the obligation to deliver monitoring reports on initiation, construction, operation and post-operation phases. If the developer fails to comply with these obligations, the Ministry may give extra time for the developer to fulfill the requirements. In cases where the developer continues to fail to comply with the requirements, the project stops.

\section{Issues in Turkey's EIA System}

Having reviewed the legal framework of Turkish EIA process, it is necessary to discuss some major shortcomings of Turkish EIA with regard to full transposition and practical implementation of EU's EIA law. Regarding the transposition of EU's EIA legislation, apart from provisions on transboundary EIA, the EIA Directive has been fully transposed into Turkish national law. In other words, Turkey's EIA By-law is not fully in line with the provisions of EIA Directive in cases where a project in Turkey is likely to have significant effects on the environment in a Member State. In such a case, Turkey has to send to the affected state a description of the project with its transboundary impacts and give other affected state a reasonable time to decide whether its wishes to participate in EIA process. Moreover, Turkey has to ensure the availability of information on project, its potential impacts on the affected state, nature of decisions which may be taken to the public and related authorities in affected Member State. In addition to this, Turkey has to enable effective public participation process in which the affected public and public authorities can contribute to decision making process. However, currently there is no change in the compliance status of the provisions related to transboundary EIA. This lack of compliance also prevents Turkey from participating in a transboundary EIA process in cases where the adverse environmental impacts of a proposed project in another Party will likely to affect Turkey. Lack of compliance with transboundary provisions also causes deficiencies in access to information, public participation in decision making and access to justice in environmental matters.

Aside from the shortcomings in full transposition of the EIA Directive into national legislation, Turkish EIA system suffers from problems related to effective practical application of the EIA process. In many cases, local governments and national government tend to neglect environmental protection by giving primacy to economic development and growth. It should be noted that, in the last twenty years, the consideration given to environmental preservation has risen. The gradual change of mentality also influenced the number of projects and policies introduced by governments to stop environmental degradation and promote sustainable development. However, despite these efforts, for countless urban development projects, 
environmental concerns remain to be secondary when compared to economic concerns. Hence, as long as the mindset that gives primacy to economic growth and development over environmental preservation persists, it is less likely that Turkey will enable effective practical application of EIA.

Similar to aforementioned problem, another issue in Turkish EIA is lack of development of a substantial environmental culture. ${ }^{21}$ In other words, majority of society and public authorities do not have a learned behavior, practice and knowledge about environmental protection, ecosystem and all other natural resources that is interrelated with human life. The lack of environmental culture also affects the quality of the decisions made regarding EIA applications. The higher number of "EIA Positive" and "EIA is Not Required" decisions reflects the low level of development of environmental culture.

Besides above mentioned problems, there are significant shortcomings with regard to the EIA process itself. Firstly, there is a lack of substantial and adequate technical guidance for EIA implementation. ${ }^{22}$ This shortcoming resulted in incorrect and poor implementation especially during the early years of the introduction of EIA in Turkey. In the absence of wellestablished technical guidelines, environmental authorities, agencies and inexperienced developers conduct a weak EIA process. Poorly prepared EIA reports can be given as an example to this issue. Without proper guidelines, it is not possible to prepare a complete and adequate report that is necessary for a proper assessment process. Secondly, there are problems regarding access to and availability of environmental data. ${ }^{23}$ There is a lack of up-todate online environmental database that includes procedures, programmes and recent developments regarding environmental matters. There is inadequate environmental information and database on official website of the Ministry of Environment and Urbanization on environmental matters in general, EIA in particular. In addition to this, majority of the published and online documents are in Turkish. This is a significant limitation for many international organizations, agencies and institutions which aims to get more

${ }^{21}$ Nükhet Turgut, "EIA with Reference to the EU Directive, Environmental Policy and Law", 33/3-4, 2003, p.169 Retrieved from http://iospress.metapress.com/content/4e5ubp9kh4pwef9f/ (Accessed on December 12, 2012).

22 Balsam Ahmad and Christopher Wood, "A Comparative Evaluation of the EIA Systems in Egypt, Turkey and Tunisia”, Environmental Impact Assessment Review, 22 (3), 2002, p. 226. Retrieved from http://www.scirp.org/journal/PaperInformation.aspx?PaperID=26011 (Accessed on November 27, 2012).

${ }^{23}$ Aynur Aydın Coşkun and Özhan Türker, "Analysis of Environmental Impact Assessment (EIA) System in Turkey”, Environmental Monitoring and Assessment, 175, 2010, p. 223. Retrieved from http://link.springer.com/article/10.1007\%2Fs10661-010-1507-3\#page-1 (Accessed on February 2, 2013) 
information about environmental matters in Turkey. Thirdly, public participation meetings are not carried out effectively. Especially in smaller areas where public is not aware of the negative impacts of development project on environment, there is a tendency to carry out public meetings just to prove that developer complies with the EIA procedure. In such cases, a public meeting is held without a substantial contribution from the affected public. Hence, this impairs the quality of the assessment process and results in cases where several significant negative impacts of a project are ignored or unrecognized. Another issue related with public participation is about poor representation of public's opinions, recommendations and concerns in decision-making process. Relevant authorities and project developer should take public's opinions and concerns seriously and make a decision accordingly. Carrying out effective and comprehensive public participation process does not serve to any purpose unless the opinions of the public are reflected in decision making process. Fourthly, there is insufficient practice of post-decision monitoring and control in Turkish EIA process. ${ }^{24}$ Postdecision monitoring and control are essential components of best practice and they are significant for the quality of EIA process in Turkey. Due to insufficient and loose practice of monitoring and control, overall quality of EIA process deteriorates.

Some of the above mentioned shortcomings are also pointed out by the EU in its progress reports. Each year the European Commission prepares a report which assesses the progress made by Turkey towards fulfilling the requirements for EU membership. This report mainly gives an assessment on three subjects: situation in Turkey in terms of political criteria for membership, situation in Turkey in terms of economic criteria for membership, Turkey's ability to take on the obligations of membership. Turkey's compliance with EU's environmental acquis is assessed under 'Turkey's ability to take on the obligations of membership' section. In terms of environmental matters, progress reports cover many subjects including EIA and SEA. With regard to Turkey's compliance with the EIA Directive, progress reports mainly underline that "procedures for transboundary consultations have not been aligned with the acquis and Turkey has not yet sent its draft for general bilateral agreements on EIA cooperation in a transboundary context to the relevant Member States. ${ }^{, 25}$

\footnotetext{
${ }^{24}$ Ahmet Çevlik and Fuat Budak, "An Evaluation of the Environmental Impact Assessment System in Turkey: Practitioners View", Research Journal of Environmental Sciences 1(4), 2007, p. 157. Retrieved from http://scialert.net/fulltext/?doi=rjes.2007.151.158 (Accessed on May 19, 2012).

${ }^{25}$ European Commission, "Commission Staff Working Document: Turkey 2014 Progress Report”, SWD (2014) 307 final, Brussels, p.69. Retrieved from
} 
With respect to the SEA Directive, progress reports underline the fact that the transposition of SEA Directive is underway but it has not yet been completed. ${ }^{26}$ In 2003, as a candidate country, Turkey launched a project to adopt and implement the SEA Directive. Supported by Netherlands, this project helped Turkey to increase its institutional capacity and gain knowledge and experience on SEA. Within the scope of the project, Turkey prepared a draft By-law on SEA. Following the preparation of the draft, Turkey has initiated several capacity improvement projects that will help the draft by-law on SEA enter into force until 2011. However, this has not been realized yet. Hence, there is a growing need to take necessary steps to increase capacity, expertise and practice on SEA that will lead to full transposition and effective implementation.

Another important issue that is addressed in several progress reports is the lack of overall progress in administrative capacity. Issues that reports have pinpointed about administrative functioning and capacity have implications on effective implementation of the EIA. As Turkey 2012 Progress Report underlines, "at the newly created Ministry of Environment and Urbanization, a balance between the environment and development agendas has still to be found and there are in particular concerns over the lack of attention paid to environmental considerations in the implementation of major infrastructure projects, as well as the willingness and ability to ensure a meaningful public consultation process, including with environmental NGOs. There are some concerns related to the loss of provincial competences in the field of environmental management, in particular as regards inspection, monitoring and permitting., 27

Having reviewed EU's evaluation of Turkey's progress on Environment chapter, it is safe to conclude that there are persistent problems with regard to full transposition of EU's EIA legislation. In addition to this, as progress reports underline, it is not sufficient for Turkey to harmonize its environmental legislation with acquis, but it also needs to strengthen its institutional and administrative capacity to enable full transposition and effective practical application of EIA process.

http://ec.europa.eu/enlargement/pdf/key_documents/2014/20141008-turkey-progressreport_en.pdf (Accessed on December 19, 2014).

${ }^{26}$ Ibid, p.69.

${ }^{27}$ European Commission, "Commission Staff Working Document: Turkey 2012 Progress Report”, SWD (2012) 336 final, Brussels, 201, p.83. Retrieved from http://ec.europa.eu/enlargement/pdf/key_documents/2012/package/tr_rapport_2012_en.pdf (Accessed on March 15, 2013). 


\section{Conclusion and Recommendations}

Twenty years have passed since the introduction of EIA system in Turkey. Despite many shortcomings in transposition of the EIA Directive and practical application of the EIA system, EIA started to become an important tool for planning as well as environmental preservation due to growing environmental awareness in Turkey. By introducing certain measures, Turkey would be able to strengthen its EIA law and practice and ensure environmentally-friendly planning, environmental preservation and sustainable development.

Full transposition of EIA Directive into national legislation is an important step since effective implementation requires the incorporation of legislative procedures fully. By introducing provisions that cover transboundary EIA, Turkey will make a step towards fulfilling its objective to fully align its environmental legislation with EU's environmental law. In addition to this, introducing transboundary provisions will assist Turkey to apply more integrated approach to protection of the environment.

To improve the effectivity of practical application, Turkey needs to take several measures. Firstly, there is a need for strengthening public participation in the EIA process. This could be achieved through strengthening provisions for consultation and public participation as well as training and informing public about their rights to access environmental information. Environmental authorities and agencies can held workshops and meetings for public and inform them about the importance and benefits of public involvement in environmental decision-making process. Secondly, there is a need for introducing mechanisms to ease the availability of and access to up-to-date environmental information and data. In 2008, former Ministry of Environment and Forestry launched a project co-funded by EU and Turkey, called Turkish Environmental Information Exchange Network $(\text { TEIEN })^{28}$. TEIEN is an electronic network which seeks to ease the access and sharing of environmental data between institutions which are dealing with environmental matters. It aims to provide up-to-date environmental information as well as increase the exchange of environmental data between different institutions. Successful implementation of TEIEN project will increase availability, transparency and accuracy of environmental information and data. Thus, it will play significant role in effective implementation of EIA process as well as other environmental procedures. Thirdly, widening the scope of capacity-building efforts is recommended. ${ }^{29}$

\footnotetext{
${ }^{28}$ For more information on TEIEN, see http://teienportal.cob.gov.tr/ (Accessed on February 6, 2013).

${ }^{29}$ Sally E. R. Innanen, "Environmental Impact Assessment in Turkey: Capacity Building for European Union Accession, Impact Assessment and Project Appraisal", 22 (2), 2004, p.149.
} 
In 2006, former Ministry of Environment and Forestry established the "EIA Training and Information Centre" to provide services in three areas: training, research, information and communication. Centre aims to support the improvement of implementation of EIA in Turkey. However, since its establishment, this centre stayed as a mere branch inside the General Directorate of EIA, Permits and Inspection. There is a need for improving the functioning of EIA Training and Information Centre. It could be done through opening libraries, sending monthly newsletters to subscribers and increasing the quality and accessibility of the environmental information available to public. In addition to this, increasing the number and the quality of trainings that EIA Training and Information Centre provide is recommended since training of EIA practitioners, specialists and other relevant personnel plays a significant role in increasing administrative capacity and effective implementation of EIA process. Lastly, carrying out long term empirical and theoretical research on EIA would help EIA practitioners to overcome some of long-lasting methodological problems.

In conclusion, despite many shortcomings in transposition of the EIA Directive and practical application of the EIA system, EIA has become a widely used information-driven tool for environmental management and preservation. By introducing necessary measures and mechanisms to overcome these shortcomings, Turkey will be able to improve the quality of EIA system performance in the short term. In the long term, improving the effectivity of EIA will contribute to the improvement of environmental quality and general conditions for sustainable development in Turkey.

\section{Bibliography}

Ahmet Çevlik and Fuat Budak, "An Evaluation of the Environmental Impact Assessment System in Turkey: Practitioners View", Research Journal of Environmental Sciences 1(4), 2007, p. 151-158. Retrieved from http://scialert.net/fulltext/?doi=rjes.2007.151.158 (Accessed on May 19, 2012).

Aynur Aydın Coşkun and Özhan Türker, "Analysis of Environmental Impact Assessment (EIA) System in Turkey", Environmental Monitoring and Assessment, 175, 2010, p. 213-226. Retrieved from http://link.springer.com/article/10.1007\%2Fs10661-010-1507-3\#page-1 (Accessed on February 2, 2013).

Aysel Alp, “AVM, golf, toplu konut projeleri ÇED’den muaf tutuldu”, Hürriyet, 26 November 2014, http://www.hurriyet.com.tr/ekonomi/27647444.asp (Accessed on December 20, 2014). 
Balsam Ahmad and Christopher Wood, "A Comparative Evaluation of the EIA Systems in Egypt, Turkey and Tunisia", Environmental Impact Assessment Review, 22 (3), 2002, p. 213-264. Retrieved from http://www.scirp.org/journal/PaperInformation.aspx?PaperID=26011 (Accessed on November 27, 2012).

Christopher Wood, "Environmental Impact Assessment: A Comparative Review", 2nd Edition, Harlow: Prentice Hall, 2003, 405 p.

Club of Rome, The Limits to Growth, http://www.clubofrome.org/?p=326 (Accessed on March 2, 2013).

European Commission, "Commission Staff Working Document: Turkey 2012 Progress Report", SWD (2012) 336 final, Brussels, 201, 94 p. Retrieved from http://ec.europa.eu/enlargement/pdf/key_documents/2012/package/tr_rapport_ 2012_en.pdf (Accessed on March 15, 2013).

European Commission, "Commission Staff Working Document: Turkey 2014 Progress Report", SWD (2014) 307 final, Brussels, 81 p. Retrieved from http://ec.europa.eu/enlargement/pdf/key_documents/2014/20141008-turkeyprogress-report_en.pdf (Accessed on December 19, 2014).

European Commission, Glossary: Acquis Communautaire, http://europa.eu/legislation_summaries/glossary/community_acquis_en.htm (Accessed on April 20, 2013).

International Association for Impact Assessment (IAIA), Principles of Environmental Impact Assessment Best Practice, 1999, Retrieved from http://www.iaia.org/publicdocuments/specialpublications/PrincipleofIA_web.pdf (Accessed on July 19, 2012).

John Glasson et al., "Introduction to Environmental Impact Assessment", 3rd Edition, New York: Routledge, 2005, 423 p.

Neil Craik, "The International Law of Environmental Impact Assessment: Process, Substance and Integration", UK: Cambridge University Press, 2010, 332 p.

Nükhet Turgut, "EIA with Reference to the EU Directive, Environmental Policy and Law", 33/3-4, 2003, p. 163-169. Retrieved from http://iospress.metapress.com/content/4e5ubp9kh4pwef9f/ (Accessed on December 12, 2012).

Official Gazette, Environmental Code No.2872, Turkish Official Gazette, 18132, 11 August 1983. Retrieved from http://en.hukuki.net/index.php?topic=1323.0; wap2 (Accessed on November 5, 2012).

Official Gazette, Environmental Impact Assessment Regulation, Turkish Official Gazette, 21489, 7 February 1993. Retrieved from http://www.resmigazete.gov.tr/main.aspx?home=http://www.resmigazete.gov.t 
r/arsiv/21489.pdf\&main=http://www.resmigazete.gov.tr/arsiv/21489.pdf (Accessed on November 5, 2012).

Official Gazette, Environmental Impact Assessment Regulation, Turkish Official Gazette, 23028, 23 June 2002. Retrieved from http://faolex.fao.org/docs/html/tur23762.htm (Accessed on November 12, 2012).

Official Gazette, Environmental Impact Assessment Regulation, Turkish Official Gazette, 28784, 3 October 2013. Retrieved from http://www.resmigazete.gov.tr/eskiler/2013/10/20131003-3.htm (Accessed on November 12, 2014).

Official Gazette, Environmental Impact Assessment Regulation, Turkish Official Gazette, 29186, 25 November 2014. Retrieved from http://www.resmigazete.gov.tr/eskiler/2014/11/20141125-1.htm (Accessed on December 19, 2014).

Official Gazette, Environmental Impact Assessment Regulation, Turkish Official Gazette, 24777, 6 June 2002. Retrieved from rec_id $=026193 \&$ database $=$ faolex\&search_type $=$ link\&table $=$ result\&lang $=$ eng \& format_name=@ERALL (Accessed on November 12, 2012).

Official Gazette, Environmental Impact Assessment Regulation, Turkish Official Gazette, 25318, 16 December 2003. Retrieved from http://faolex.fao.org/docs/texts/tur41439.doc (Accessed on November 14, 2012).

Official Gazette, Environmental Impact Assessment Regulation, Turkish Official Gazette, 26939, 17 July 2008. Retrieved from http://www.csb.gov.tr/dosyalar/images/file/ced_yonetmeligi_english.doc (Accessed on November 12, 2012).

Official Gazette, Law No.5491 amending the Environmental Law No.2872, Turkish Official Gazette, 26167, 13 April 2006. Retrieved from http://faolex.fao.org/cgi-

bin/faolex.exe?rec_id $=049688 \&$ database $=$ faolex\&search_type $=$ link\&table $=$ res ult\&lang=eng\&format_name=@ERALL. (Accessed on November 14, 2012).

Sally E. R. Innanen, "Environmental Impact Assessment in Turkey: Capacity Building for European Union Accession, Impact Assessment and Project Appraisal", 22 (2), 2004, p.141-151. Retrieved from http://www.ingentaconnect.com/content/tandf/iapa/2004/00000022/00000002/a rt00007 (Accessed on May 6, 2012).

Simon Marsden, "Strategic Environmental Assessment in International and European Law: A Practitioner's Guide”, London; Sterling, VA: Earthscan, 2008, 330 p.

Turkish Environmental Information Exchange Network (TEIEN), http://teienportal.cob.gov.tr/ (Accessed on February 6, 2013). 